\title{
Effects of bioturbation by the lugworm Arenicola marina on cadmium uptake and distribution in sandy sediments
}

\author{
Allan Dahl Rasmussen*, Gary Thomas Banta, Ole Andersen \\ Department of Life Sciences and Chemistry, Roskilde University, PO Box 260 (17.2), DK-4000 Roskilde, Denmark
}

\begin{abstract}
The effect of bioturbation by the lugworm Arenicola marina on uptake and distribution of cadmium in sediment was assessed using laboratory sediment cores. Carrier-free ${ }^{109} \mathrm{Cd}$ was added to the water phase each day. Bioturbation (irrigation) was measured using bromide ( $\mathrm{Br}^{-}$) as a tracer for water movement. In cores without lugworms all $\mathrm{Cd}$ was found in the surface sediment where it continued to build up over $16 \mathrm{~d}$ of exposure. In cores containing lugworms a distinct peak of $\mathrm{Cd}$ was found both at the sediment surface and, after a few days, at the feeding pocket of the worm $(10$ to $15 \mathrm{~cm}$ depth). During the $16 \mathrm{~d}$ of exposure this subsurface peak broadened and eventually Cd was found in all depths from top to feeding depth of the individual worm. Compared to sediment cores without worms, the presence of lugworms more than doubled the rate of removal of $\mathrm{Cd}$ from water to sediment. This was attributed to an increased turnover of sediment (due to feeding activity), an increased sediment surface area (due to fecal casts, head shaft, tube and irrigation of the whole burrow) and an increased contact of Cd-labelled water with potential binding sites in the sediment due to irrigation. Exposure to $1 \mathrm{ppm} C d$ reduced the fractional rate: at which lugworms removed Cd from the water (as $\%$ of $\mathrm{Cd}$ in the water). The total $\mathrm{Cd}$ flux to the sediment, however, was much greater due to the higher Cd concentrations in the water Water fluxes estimated using $\mathrm{Br}^{-}$as a solute tracer revealed a 10 - to $20-$ fold increase in water exchange of the sediments when lugworms were present. This enhanced water flux was not affected by exposure of lugworms to $1 \mathrm{ppm} \mathrm{Cd}$. The results indicate that the presence of bioturbating infauna influences both the uptake rates of trace metals in near-shore sediments and the distribution of those metals.
\end{abstract}

KEY WORDS: Arenicola marina - Cadmium - Irrigation Bioturbation - Sediments

\section{INTRODUCTION}

Sediment-dwelling invertebrates are important components of near-shore areas such as the intertidal zone of Danish fjords and the Wadden Sea (Reise 1995). The polychaete Arenicola marina (the lugworm) is one of the dominant animals in these environments. Lugworms in general (Arenicola and Abarenicola) are distributed world wide (Wells 1963, Reise 1995), and the effects of their intense bioturbation can easily be seen in the form of sand fecal casts.

Arenicola marina lives head down in J-shaped tubes at various depths, depending on the worm's size

·E-mail: adr@ruc.dk as well as sediment composition. Bioturbation by $A$. marina can be divided into particle and solute mixing: (1) A. marina mixes particles by feeding on the sediment at depth (typically 10 to $20 \mathrm{~cm}$ ) and defecating at the sediment surface. The sediment removed at depth is replaced by surface sediment falling down into the head shaft, leading to a conveyor-belt-like circular movement of sediment particles (Rijken 1979). (2) In addition to particle mixing, solute mixing occurs as overlying water is pumped through the tube from tail to head (opposite direction of the sediment movement), thereby oxygenating the line of gill filaments along each side of the worm (Wells 1966). This water is pumped out of the tube into the sediment at the feeding depth. 
The bioturbating effect of Arenicola marina thus results in various chemical changes in the sediment, such as increased oxygen penetration due to the resplratory water current and increased $\mathrm{pH}$ due to removal of acidic metabolites (Krantzberg 1985). It also influences the porewater nutrient profiles, causing, for example, increased nitrate and decreased ammonia concentrations at depth near lugworm burrows (Hüttel 1990) as well as decreasing rigidity of the sediment by creating open burrows (Jones \& Jago 1993). Bioturbators such as $A$. marina thus have important effects on the biogeochemical and physical nature of the sediments in which they live.

Human activities have dramatically increased the cycling of heavy metals in the environment (Nriagu 1988), and it has been estimated that $6.3 \mathrm{t}$ of cadmium reaches Danish waters per year, mostly originating from atmospheric fall out (Jensen \& Markussen 1993). The distribution of cadmium in coastal areas is affecled by numerous factors. Cadmium in the form of $\mathrm{Cd}^{2+}$ reaching intertidal waters will be chelated by organic ligands in water or form mixed aqua complexes with available anions such as chloride and carbonate ions (Mantoura et al. 1978). Inorganic Mn and Fe oxides and hydroxides in sediments bind $\mathrm{Cd}(\mathrm{Cd}$ is used here to specify the sum of all species of $\mathrm{Cd}^{2+}$ present) at high $\mathrm{pH}$ and oxidising conditions and release it again at low $\mathrm{pH}$ and reducing conditions (Förstner \& Wittmann 1979, Simpson 1981). Under reducing conditions, Mn and $\mathrm{Fe}$ are reduced to free ions which then bind to sulphide minerals (FeS and MnS). These sulphides will exchange $\mathrm{Fe}$ and $\mathrm{Mn}$ ions with $\mathrm{Cd}$, forming insoluble complexes (Di Toro et al. 1990). Ca binding thus occurs during both oxidising and reducing conditions in sediments. The affinity of organic ligands in sediment for $\mathrm{Cd}$ is high and nearly independent of changes in $\mathrm{pH}$ (Davies-Colley et al. 1984). The amounts of organic material available to bind $\mathrm{Cd}$ in most sediments are low compared to the amounts of inorganic material, so most $\mathrm{Cd}$ is bound to sediment particle surfaces or in insoluble mineral complexes as opposed to organic matter. Given that bioturbation affects the physical and biogeochemical nature of the sediment (e.g. how oxidised it is), it is likely that bioturbation will also affect $\mathrm{Cd}$ binding in the sediment.

Experiments concerned with the influence of benthic organisms on the distribution and uptake of toxic metals in sediment are scarce, although the uptake by benthic organisms themselves is well documented (see e.g. Klerk \& Weis 1987). One study by Everaarts \& SaralaDevi (1996) focusing on the relationships between $\mathrm{Cd}$ distribution in lugworms and sediments showed that lugworms did affect the vertical distribution of $\mathrm{Cd}$ in the sediment column. Thomann et al. (1993) found that bioturbation increased the release of $\mathrm{Cd}$ from the contaminated sediments at Foundry Cove, New York USA.

The objective of the present study was to examine the effects of bioturbation by lugworms on the uptake and distribution of dissolved $\mathrm{Cd}$ in sandy sediments. Furthermore, we were interested in whether sublethal concentrations of Cd would affect Arenicola marina's bioturbation. The experimental work was performed using radioactive $\mathrm{Cd}\left(\gamma\right.$-emitting $\left.{ }^{109} \mathrm{Cd}\right)$ as a tracer for Cd movement

\section{MATERIALS AND METHODS}

Experimental set-up. Sediment, lugworms and seawater were collected during July 1995 in Roskilde Fjord, near Frederikssund, Denmark. Sediment temperature was $18^{\circ} \mathrm{C}$ and water temperature was $19^{\circ} \mathrm{C}$ Water salinity was $15 \%$. Sediment was homogenised and sieved with a $1 \mathrm{~mm}$ sieve. The experiment was conducted at $15^{\circ} \mathrm{C}$ with water of $15 \%$ salinity.

All materials were brought to the laboratory, where 28 PVC tubes were filled with sediment to a height of $25 \mathrm{~cm}$. The tubes had an inner diameter of $8.2 \mathrm{~cm}$, which corresponds to a sediment core surface area of $53 \mathrm{~cm}^{2}$. Seawater $(250 \mathrm{ml})$ was added carefully without resuspending the sediment. Each tube was fitted with an air stone to aerate and stir the water. The next day the water in all of the cores was changed and 1 lugworm was added to each of 20 cores, leaving 8 cores as controls without lugworms. One worm per core was equivalent to 190 ind. $\mathrm{m}^{-2}$, which represents the upper end of the range of natural densities (Cadée 1976). Wet weight (ww) of lugworms was $1.13 \pm 0.47 \mathrm{~g}$ (mean \pm $\mathrm{SD}$ ), except in the 3 cores sectioned on the last day of the experiment, for which larger worms were used $(5.44 \pm 1.80 \mathrm{~g})$. Lugworms that failed to burrow within $10 \mathrm{~min}$ were replaced with new lugworms. The tubes were divided into 4 groups (Table 1).

At the start of the experiment (Day 0) water was removed and $250 \mathrm{ml}$ of fresh seawater carefully added, after which, for 3 of the groups $(\mathrm{C}+\mathrm{A}+$ and $\mathrm{A}+\mathrm{Cd}$; Table 1), $\mathrm{Cd}$ and/or ${ }^{109} \mathrm{Cd}$ (specific activity $1.30 \mathrm{mCi}$ $\mathrm{mg}^{-1}$, DuPont, Brussels, Belgium) in $50 \mathrm{ml}$ seawater was added to each tube so the final volume was $300 \mathrm{ml}$. Each of these tubes then initially contained either $2600 \mathrm{cpm} \mathrm{ml}^{-1}$ (= $590 \mathrm{fg} \mathrm{Cd} \mathrm{ml}^{-1}$ ) (groups C+ and A+) or $2600 \mathrm{cpm} \mathrm{ml}^{-1}$ and 1 ppm $\mathrm{Cd}$ (group $\mathrm{A}+\mathrm{Cd}$ ). Tubes in the fourth group (A-) contained $300 \mathrm{ml}$ of Cd-free water (Table 1). Water was changed and $\mathrm{Cd}$ added each day for the next $16 \mathrm{~d}$. During all water changes care was taken not to disturb the sediment surface 1.5 to $8 \mathrm{~h}$ after the water was changed 1 core from each group was sectioned as described below on Days 0,1 , $3,6,8,10,13$ and 16 . Each day after the water was 
Table 1. Summary of the experimental design and explanation of the group terms. C: control (no lugworm present); A: Arenicola marina present. + or -: presence or absence, respectively, of a lugworm, of trace ${ }^{109} \mathrm{Cd}$ or of $1 \mathrm{ppm} \mathrm{Cd}$ in a given group

\begin{tabular}{|cccc|}
\hline Group & Lugworm & ${ }^{109} \mathrm{Cd}$ & $1 \mathrm{ppm} \mathrm{Cd}$ \\
\hline $\mathrm{C}+$ & - & + & - \\
$\mathrm{A}+$ & + & + & - \\
$\mathrm{A}+\mathrm{Cd}$ & + & + & + \\
$\mathrm{A}-$ & + & - & - \\
\hline
\end{tabular}

changed and new $\mathrm{Cd}$ was added, $1 \mathrm{ml}$ samples of the overlying water were taken at regular time intervals from each core and the ${ }^{109} \mathrm{Cd}$ activity was measured as described below.

The potential for errors due to binding of ${ }^{109} \mathrm{Cd}$ to the plastic surfaces of the experimental cores was checked by incubating water with added ${ }^{109} \mathrm{Cd}$ for $24 \mathrm{~h}$ in 4 core tubes without sediment. No significant loss of ${ }^{109} \mathrm{Cd}$ from the water was observed (data not shown).

Sectioning of sediment cores. Cores were sectioned at intervals of 0.5 or $1 \mathrm{~cm}$ from the top, increasing to intervals of 1,2 or $3 \mathrm{~cm}$ deeper in the core. During sectioning it was noted at what depth the lugworm was found. In cores containing lugworms, the sediment surface was often very uneven, so the depth scale given represents an average depth.

Sediment from each depth interval was placed in a $20 \mathrm{ml}$ plastic vial and the vial closed using a modified cap (containing small holes and a $25 \mathrm{~mm}$ Whatman GF/C filter; Thomsen \& Kristensen 1997). Vials were inverted and placed in plastic centrifuge tubes and porewater was extracted by centrifugation $(1500 \times g$ for $1 \mathrm{~min}$ ). In addition, wet and dry densities for each sediment sample were determined. Porosity was calculated based on water loss after drying (overnight at $105^{\circ} \mathrm{C}$ ) a known volume of sediment

Cadmium measurements. The amounts of ${ }^{109} \mathrm{Cd}$ in samples of surface water collected every day and of dry sediment and porewater obtained after cores were sectioned were measured using a Packard Cobra ${ }^{\text {TM }}$ II auto-gamma counter. The ${ }^{109} \mathrm{Cd}$ activity of dry sediment was multiplied by a correction factor of 1.565 to compensate for absorption of gamma emissions by the sediment itself. This correction factor was established by measuring gamma-emissions for a known addition of ${ }^{109} \mathrm{Cd}$ to sediment samples.

Irrigation measurements. To measure water exchange between surface water and sediment and irrigation by Arenicola marina, ca $10 \mathrm{mM} \mathrm{KBr}$ was added as a solute tracer to the overlying water prior to sectioning of each core (including A-cores) as described by Aller \& Aller (1992). Cores without A. marina had $\mathrm{KBr}$ added approximately $20 \mathrm{~h}$ before sectioning while for cores containing $A$. marina, $\mathrm{KBr}$ was added approximately $1.5 \mathrm{~h}$ before sectioning. This difference in time intervals was necessary as lugworm bioturbation greatly enhances the $\mathrm{Br}^{-}$flux. Concentration of $\mathrm{Br}^{-}$in porewater recovered from sediment sections was determined spectrophotometrically as described by Presley (1971) and a rate of $\mathrm{Br}^{-}$flux across the sediment-water interface was calculated.

Data and statistical analysis. The kinetics of removal of $\mathrm{Cd}$ from the overlying water during each $24 \mathrm{~h}$ period appeared to follow an exponential pattern (see Fig. 2). Data were therefore log-transformed and linear regressions were performed for each core on Days 0, 1, 3, 6,8 and 10 . The slope of these regressions provided estimates of $k$ in the following equation:

$$
\mathrm{Cd}=a \times \mathrm{e}^{-k t}
$$

where $\mathrm{Cd}$ is the concentration of $\mathrm{Cd}$ in the overlying water (expressed as \% of originally added $\mathrm{Cd}$ ), $a$ is a constant and $t$ is time in hours.

Differences in daily $\mathrm{Cd}$ removal rates $(k)$ were analysed by 2-way (treatment and day) factorial ANOVA. Residuals were tested (Daniel 1995) and found to be normally distributed but without homogeneous error. Data were thus log-transformed, after which both ANOVA assumptions were fulfilled. Overall ANOVA effects (both main effects and interactions) were further investigated using planned comparisons and orthogonal polynomials (Sokal \& Rohlf 1981). The planned comparisons for the treatment groups included (1) a test of the effects of the presence or absence of lugworms on Cd removal, and (2) a test for differences in Cd removal rates with lugworms present between the $2 \mathrm{Cd}$ levels (trace vs $1 \mathrm{ppm}$ ). Orthogonal polynomials were used to investigate trends (linear and quadraticj in Cd removal rate over days. The interactions between the treatment and day factor were investigated by planned comparisons which were constructed from combinations of the previously described planned comparisons for the main effects (group and days), for example, presence or absence of lugworms (treatment question 1 ) $\times$ the linear time trend.

Irrigation rates among treatment groups were analysed by analysis of covariance (ANCOVA) of logtransformed $\mathrm{Br}^{-}$data. A log-transformation was again necessary because the data, while being normally distributed, did not have homogeneous error. Furthermore, the ANCOVA assumption of parallel slopes in all groups was tested and found not to be violated ( $p \leq$ 0.95). Treatment effects were further investigated using the following planned comparisons (Sokal \& Rohlf 1981): (1) a test of the effects of the presence or absence of lugworms on $\mathrm{Br}^{-}$flux rates, (2) a test for an effect of any form of $\mathrm{Cd}$ (trace or $1 \mathrm{ppm}$ ) on lugworm 


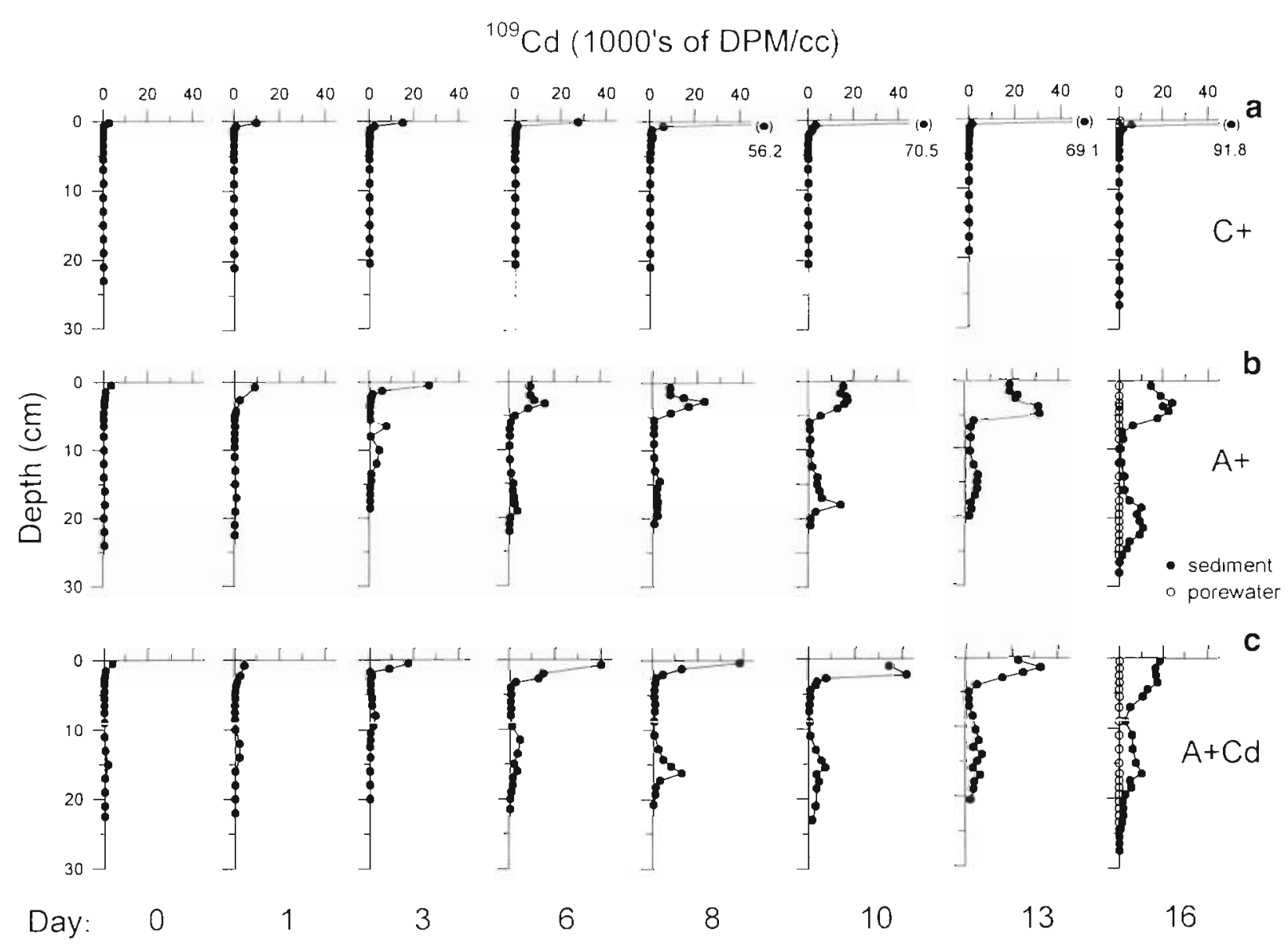

Fig. 1. Radioactive cadmium profiles for all cores from (a) group $\mathrm{C}+$ (no lugworm present, trace amounts of ${ }^{109} \mathrm{Cd}$ ), (b) group $\mathrm{A}+$ (1 lugworm present, trace amounts of ${ }^{109} \mathrm{Cd}$ ) and (c) group $\mathrm{A}+\mathrm{Cd}$ (1 lugworm present, 1 ppm Cd, trace amounts of ${ }^{109} \mathrm{Cd}$ ). Pore water ${ }^{109} \mathrm{Cd}$ (measured in all cores) shown only for Day 16

irrigation rates, and (3) a test for differences in lugworm irrigation rates between the $2 \mathrm{Cd}$ levels (trace vs $1 \mathrm{ppm})$.

Linear regressions were performed on the cumulative data of removal of ${ }^{109} \mathrm{Cd}$ from the overlying water to calculate the rates of $\mathrm{Cd}$ transfer from water to sediment in the different cores. Differences between regressions were tested using ANCOVA, which indicated that there were different slopes among treatment groups. These differences were investigated with multiple comparisons of the slope coefficients (Zar 1984).

\section{RESULTS}

\section{Cadmium profiles in sediment}

Sediment cores without lugworms accumulated $\mathrm{Cd}$ only in the upper $\mathrm{cm}$ during the $16 \mathrm{~d}$ exposure period (Fig. 1a), despite the fact that the daily water change resulted in repeated additions of ${ }^{109} \mathrm{Cd}$. Sediment con- taining lugworms (Fig. 1b, c) also accumulated large amounts of ${ }^{109} \mathrm{Cd}$ at the surface, but during the course of the experiment a distinct peak of $\mathrm{Cd}$ appeared at the depth where the worm was feeding and pumping overlying water into the sediment $(10$ to $20 \mathrm{~cm})$. This peak grew wider during the exposure period. Furthermore, the Cd-contaminated zone at the surface expanded during the experiment, indicating that $\mathrm{Cd}$ contaminated sediment was distributed throughout the sediment core. This is in sharp contrast to the control cores, in which all $\mathrm{Cd}$ remained at the sediment surface (Fig. 1a). There were no apparent differences in $\mathrm{Cd}$ profiles for worms exposed to $1 \mathrm{ppm} \mathrm{Cd}$ (Fig. 1c) and worms exposed to carrier-free ${ }^{109} \mathrm{Cd}$ (Fig. 1b), although the total $\mathrm{Cd}$ concentration levels were very different.

The subsurface $\mathrm{Cd}$ peak in both $\mathrm{A}+\left(\right.$ worm $+{ }^{109} \mathrm{Cd}$ ) and $\mathrm{A}+\mathrm{Cd}$ (worm $+{ }^{109} \mathrm{Cd}+1 \mathrm{ppm} \mathrm{Cd}$ ) cores was well correlated $(r=0.65, p \leq 0.007)$ with where the lugworm was found when each core was sectioned (data not shown). 


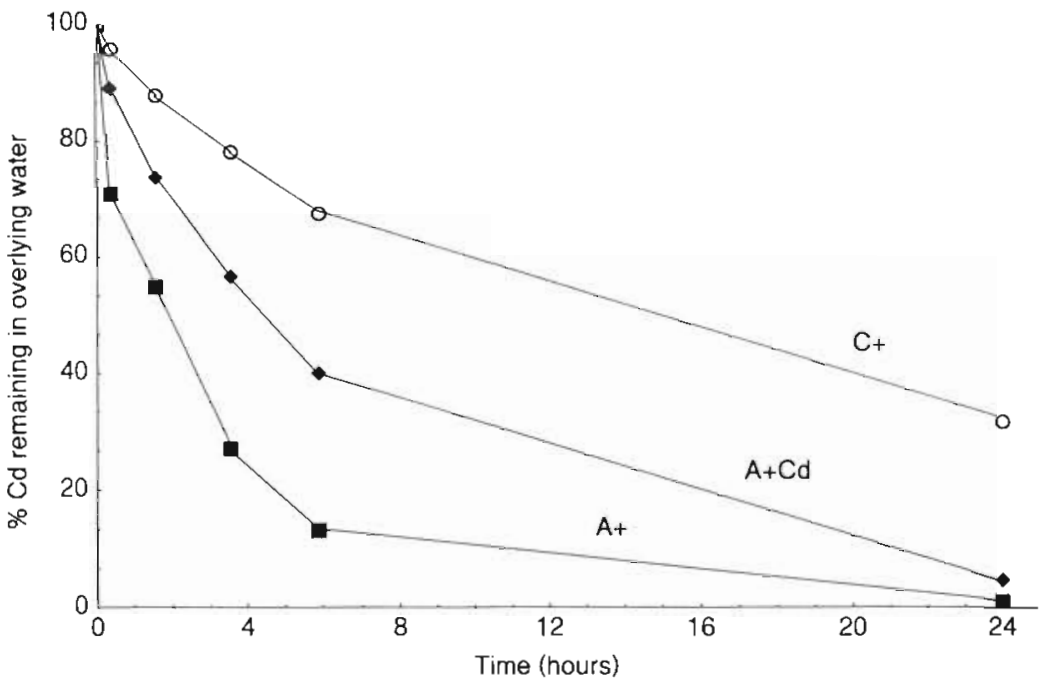

Fig. 2. Cd removal from overlying water on Day 3. Data from 1 core from each of the groups is shown. $\mathrm{C}+, \mathrm{A}+$ and $\mathrm{A}+\mathrm{Cd}$ as defined in Table 1 and Fig. 1

worms and exposure to $1 \mathrm{ppm} \mathrm{Cd}$ affected the rate of $\mathrm{Cd}$ removal, resulting in group A+ having the fastest removal and $\mathrm{C}+$ having the slowest removal rates. Furthermore, a linearly increasing trend in $k$-values over the course of the experiment was significant for both the $\mathrm{A}+$ and $\mathrm{A}+\mathrm{Cd}$ groups but not for the $C+$ group, which remained more or less constant (again test of Treatment $\times$ Day interaction, $\mathrm{p} \leq 0.01$ ).

The total Cd removal from the water phase is shown in Fig. 4. Regression analysis indicated that there was no difference in total fractional uptake of $\mathrm{Cd}$ into sediment between cores with worms exposed to carrier-free ${ }^{109} \mathrm{Cd}$ $(A+)$ and cores with worms exposed to ${ }^{109} \mathrm{Cd}$ and $1 \mathrm{ppm} \mathrm{Cd}(\mathrm{A}+\mathrm{Cd})$. Almost $100 \%$ of the added Cd was taken up during $24 \mathrm{~h}$ in $\mathrm{A}+$ and $\mathrm{A}+\mathrm{Cd}$ cores (total Cd uptake rates were $33.5 \mathrm{ng} \mathrm{Cd}$

\section{Cadmium distribution between porewater and sediment particles}

Almost all Cd was bound to sediment particles. Measurable amounts of $\mathrm{Cd}$ in porewater were found only at the sediment surface (Fig. 1, Day 16), where $\mathrm{Cd}$ concentration as well as sediment porewater concentration was highest. Even though high sediment concentrations of $\mathrm{Cd}$ were found after $16 \mathrm{~d}$ at the depth of the worm in the cores with Arenicola marina, almost no Cd was present in the porewater at the same depth.

\section{Removal of Cd from the water phase}

The daily removal of $\mathrm{Cd}$ from the overlying water was exponential (Fig. 2) and the time-Cd concentration data were thus transformed as previously described, resulting in the $k$-values which are shown in Fig. 3. The $k$-values of the $\mathrm{C}+$ group were significantly lower than in groups with lugworms, i.e. the $\mathrm{A}+$ and $\mathrm{A}+\mathrm{Cd}$ groups ( $a$ priori test of main effects, $\mathrm{p} \leq 0.0001$ ). Also, the $k$-values of the $\mathrm{A}+$ and $\mathrm{A}+\mathrm{Cd}$ groups were significantly different (a priori test, $\mathrm{p} \leq 0.0004$ ). This indicates that both the presence/absence of lug-

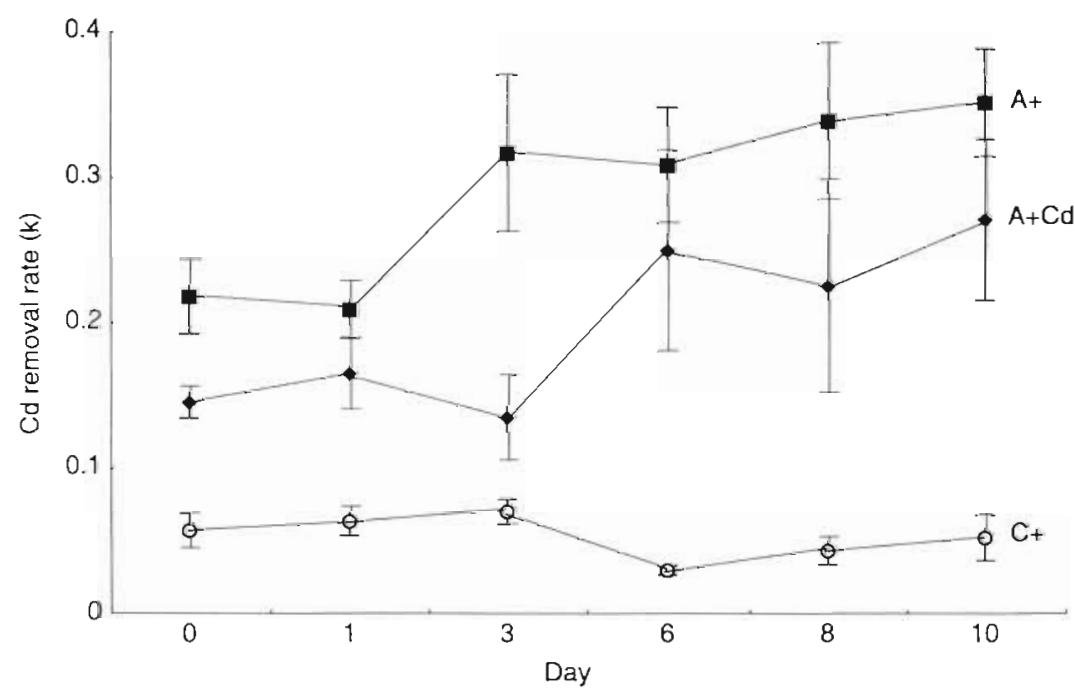

Fig. 3. Daily removal rates of $\mathrm{Cd}$ from the overlying water on the days cores were sectioned expressed as $k$-values (see 'Materials and methods' for calculation). There were fewer observations ( $n$ ) for each measurement during the course of the experiment as cores were destructively sampled. n was 7 on Day 0 . 6 on Day 1, 5 on Day 3, 4 on Day 6, 3 on Day 8 and 2 on Day 10. Error bars show \pm SE. Results of a 2-way factorial ANOVA were: Treatment, $p \leq 0.0001$; Day, not significant; and Treatment $\times$ Day, $p \leq 0.05$. See text for results of a priori tests of the Treatment and Treatment $\times$ Day effects. C+, A+ and $\mathrm{A}+\mathrm{Cd}$ as defined in Table 1 and Fig. 1 


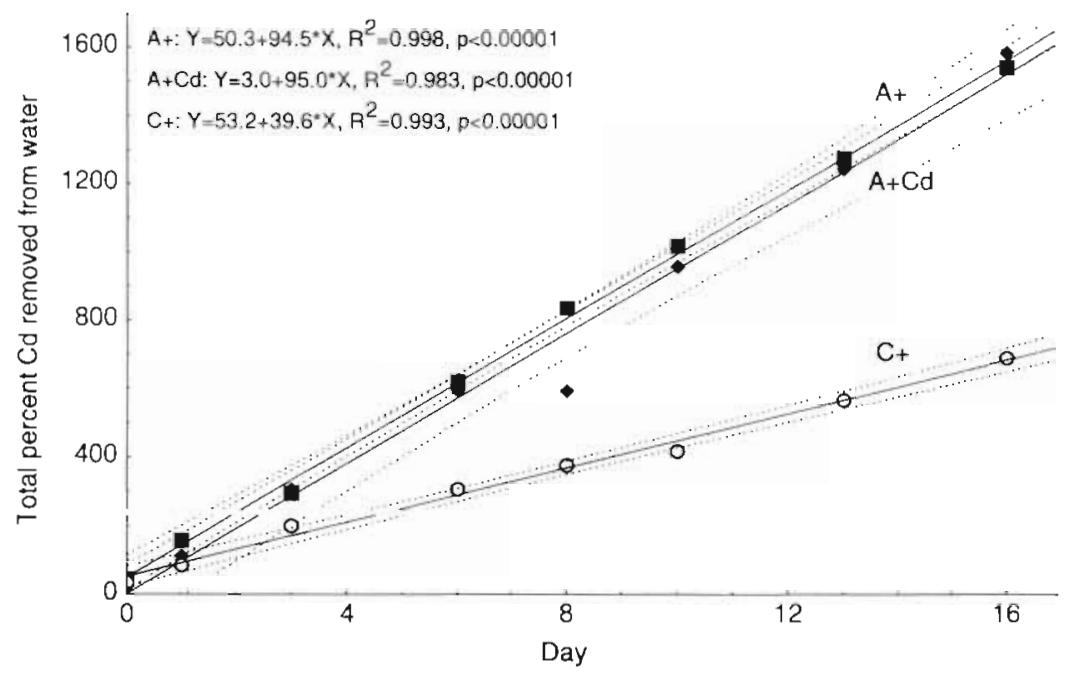

Fig. 4. Regression lines and $95 \%$ confidence limits for removal of ${ }^{109} \mathrm{Cd}$ from the water phase. The amount of ${ }^{109} \mathrm{Cd}$ removed from the water phase is expressed as the cumulative amount of ${ }^{109} \mathrm{Cd}$ removed every $24 \mathrm{~h}$ normalised to the amount of ${ }^{109} \mathrm{Cd}$ added daily (i.e. $100 \%$ equals the removal of 1 day's dose of ${ }^{109} \mathrm{Cd}$ ). Regression results are shown. $\mathrm{C}+\mathrm{A}+$ and $\mathrm{A}+\mathrm{Cd}$ as defined in Table 1 and Fig. 1 for $k$-values, is probably due to the experimental design, i.e. the amount of water in relation to the pumping capacity of the worms. Given the measured rates of irrigation (see below), all worms were capable of pumping all of the overlying water into the sediment at least once per day.

The capacity of sediments to take up Cd showed no signs of saturation, as Cd uptake proceeded at a constant rate throughout the $16 \mathrm{~d}$ exposure period. Sediment cores containing lugworms took up more than twice the amount of $\mathrm{Cd}$ that cores without lugworms took up (Fig. 4) . Linear regressions of Cd uptake versus exposure time all had good fits $\left(\mathrm{R}^{2}>0.97\right)$, indicating that $\mathrm{Cd}$ uptake was constant and suggesting that all lugworms were active throughout the experiment.

\section{$\mathrm{Br}^{-}(\mathrm{mM})$}

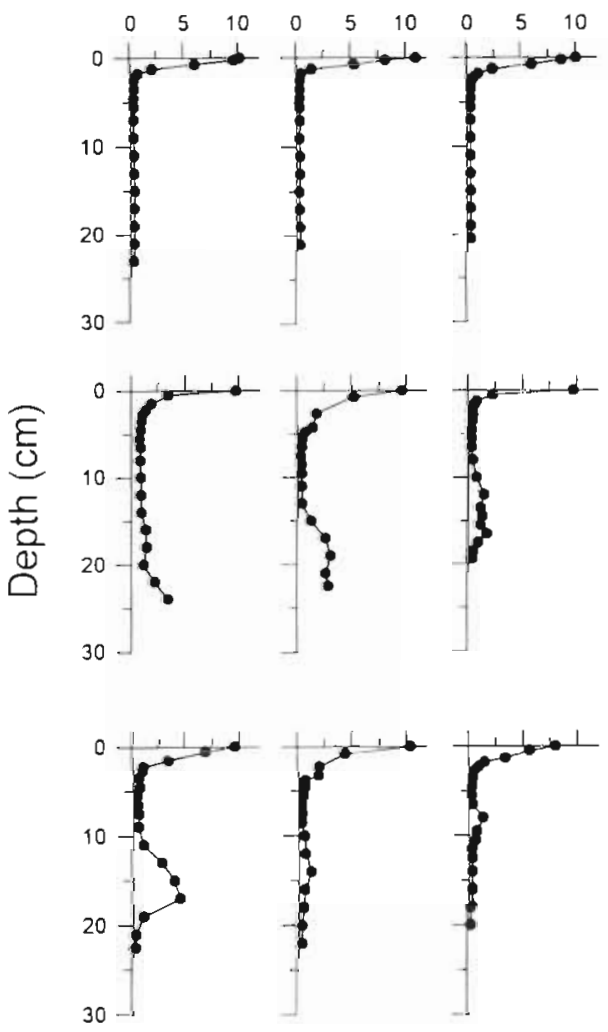

Day
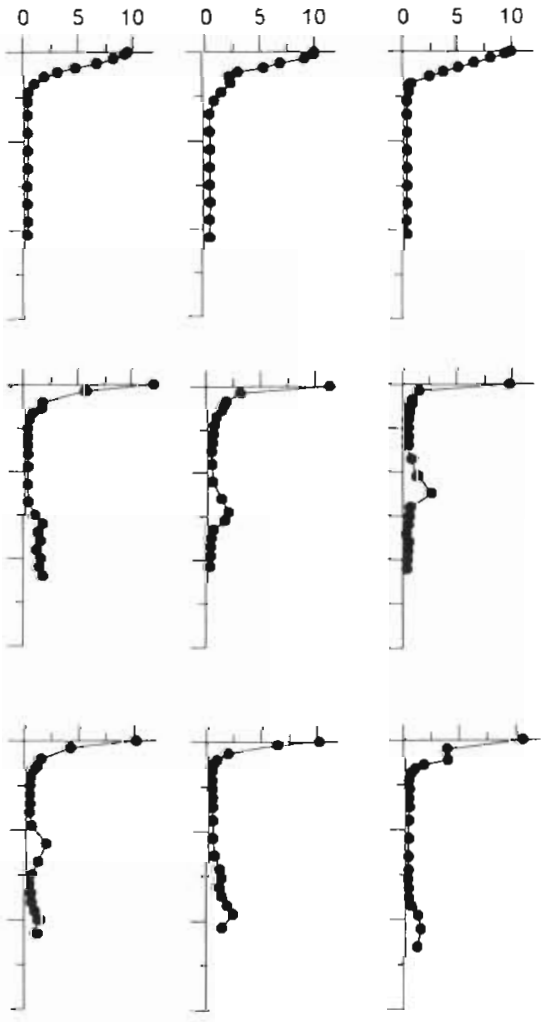

8

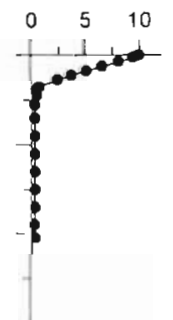

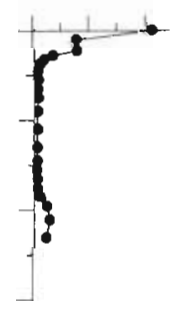
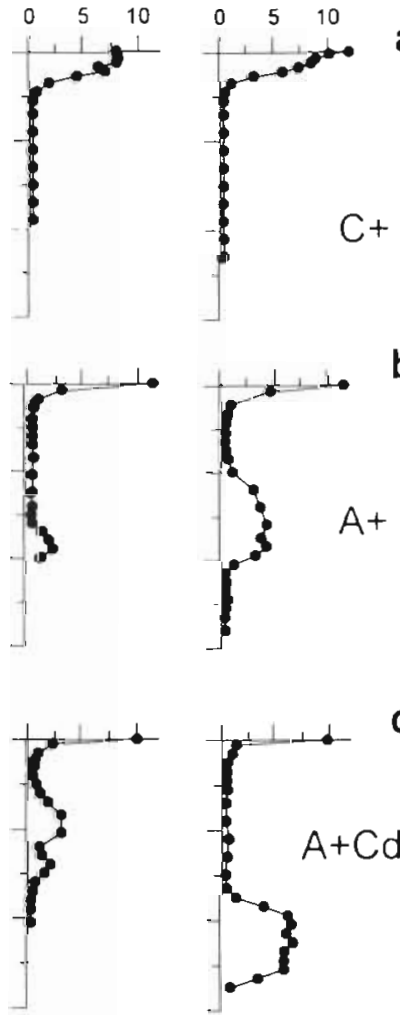

13 b

a

$+$

$c$

16

Fig. 5. Porewater bromide concentrations in all cores from (a) group $\mathrm{C}+$, (b) group $\mathrm{A}+$ and (c) group $\mathrm{A}+\mathrm{Cd}$. $\mathrm{C}+\mathrm{cores}$ were incubated with $\mathrm{Br}$ in the overlying water for 4 to $22 \mathrm{~h}$ betore sectioning. $\mathrm{A}+$ and $\mathrm{A}+\mathrm{Cd}$ cores were incubated for 1 to $2 \mathrm{~h}$. C+, A+ and $A+C d$ as defined in Table 1 and Fig. 1 


\section{Water fluxes assessed by $\mathrm{Br}^{-}$fluxes}

In control cores $\mathrm{Br}^{-}$was found in the upper layer of the sediment and decreased exponentially in concentration with depth in the core, reaching background concentrations $(0.3 \mathrm{mM})$ at the depth of a few $\mathrm{cm}$ (Fig. 5a). Modelling indicated that while the exponential form of the $\mathrm{Br}^{-}$profile in $\mathrm{C}+$ cores was indicative of diffusive transport, the rate of $\mathrm{Br}^{-}$transport was 1 to 10 times higher than molecular diffusion alone (Banta unpubl.). This suggested that $\mathrm{Br}^{-}$, and thus dissolved $\mathrm{Cd}$, was transported by diffusion-like processes enhanced by the presence of small organisms such as meiofauna in the sediment surface (Aller \& Aller 1992).

In contrast, cores containing worms developed a distinct peak of $\mathrm{Br}^{-}$at the feeding depth $(10$ to $20 \mathrm{~cm})$ within a few hours (Fig. 5 b c c). This peak was the result of rapid advective transport of the overlying water to the feeding depth by the lugworm. This pumping resulted in a transport of overlying water into the sediment that was 10 to 20 times faster than in cores without lugworms (Fig. 6, a priori test, $\mathrm{p} \leq 0.0001$ ).

Lugworm irrigation was not significantly affected by the presence of either trace levels of ${ }^{109} \mathrm{Cd}$ or $1 \mathrm{ppm}$ of $\mathrm{Cd}$ (a priori tests, $\mathrm{p} \leq 0.23$ and $\mathrm{p} \leq 0.11$, respectively). The size and placement of the subsurface peaks were not apparently different between $\mathrm{A}+$ cores and $\mathrm{A}+\mathrm{Cd}$ cores (Fig. 5b, c), also suggesting that $\mathrm{Cd}$ had no strong influence on lugworm irrigation. The depth of the subsurface $\mathrm{Br}^{-}$peak was well correlated $(\mathrm{r}=0.81, \mathrm{p} \leq$ 0.001) with the depth where the lugworm was found when the cores were sectioned (data not shown). The $\mathrm{Br}^{-}$peak was also correlated $(\mathrm{r}=0.52, \mathrm{p} \leq 0.04)$ with the depth of the sub-surface Cd peak (Fig. 1b, c).

\section{DISCUSSION}

\section{Cadmium uptake in sediment-effects of Arenicola marina}

The results presented here clearly indicate that the presence or absence of the bioturbating activities of the lugworm profoundly affected the uptake and distribution of $\mathrm{Cd}$ in sediments. Cores without lugworms took up significantly less $\mathrm{Cd}$ than cores with lugworms. Likewise, Cd was distributed to much greater depth and spread more throughout sediments with lugworms. Thus, the presence of bioturbating animals such as lugworms is important for the cycling of particle-reactive pollutants, such as $\mathrm{Cd}$. The combination of increased sediment surface due to the lugworm's tube and conveyor-belt mode of feeding, extensive movement of water due to the lugworm's irrigation and mixing of the sediment bringing new material into contact with water-borne $\mathrm{Cd}$ leads to an increased Cd uptake by the sediment and presumably a greater capacity to store Cd.

Infauna increase the contact area between sediment and overlying water due to the 3-dimensional structure of their burrows. Gerino \& Stora (1991) showed that the polychaete Nereis diversicolor increased the contact area between sediment and water by a factor of 3.2 . This was corroborated by Davey \& Watson (1995) who found that the factor ranged between 3 and 4 for the same animal. The closely related Nereis virens increased the contact area by a factor 2.8 (Kristensen 1984). In our study, the increase in relative uptake rates of $\mathrm{Cd}$ (based on percentages) was approximately 3 -fold in cores with lugworms ( $\mathrm{A}+$ and $\mathrm{A}+\mathrm{Cd}$ vs $\mathrm{C}+$ cores). An increase in contact area between sediment and water is therefore sufficient to explain our results, although it is not certain whether this was the only effect of lugworms.

Irrigation by Arenicola marina enhanced the flux of Cd-laden overlying water into sediments. We measured irrigation rates for $A$. marina of 20 to $30 \mathrm{ml} \mathrm{h}^{1}$ 
$\mathrm{g}^{-1}$ ww. Riisgård et al. (1996), using a completely different experimental technique than we did, estimated that $A$. marina (mean weight of $1.48 \mathrm{~g} \mathrm{ww}$ ) can pump approximately $60 \mathrm{ml}$ of seawater through its burrow per hour, which agrees fairly well with our estimates. These irrigation rates corresponded in our experiment to all overlying water being drawn through the burrow after 10 to $15 \mathrm{~h}$. Cadmium in the water would then potentially be exposed to available binding sites in the burrow at least once per day. However, as the water pumped through the burrow was ejected into the sediment and ultimately recirculated back to the overlying water, there would have been a progressive dilution of $\mathrm{Cd}$ in the overlying water. If sediment binding sites were not saturated, this should have resulted in an exponentially decreasing $\mathrm{Cd}$ concentration, which we did observe. In this experiment essentially all $\mathrm{Cd}$ from the overlying water was removed during the course of a day when lugworms were present. In comparison, cores without lugworms were able to remove no more than $40 \%$ of the $\mathrm{Cd}$ per day due to adsorption to the surface sediment. Only a small amount $(<3 \%)$ of $\mathrm{Cd}$ was adsorbed or taken up by the worm itselt (data not shown).

Studies by Hüttel (1990) and G. T. Banta, M. Holmer, M. H. Jensen \& E. Kristensen (unpubl.) have shown that bioturbation by Arenicola marina substantially oxidises the sediment, especially at depth. Despite the ability of lugworms to oxidise sediments and remove sulphides, thus reducing mechanisms responsible for $\mathrm{Cd}$ binding, our results indicate that oxidised sediments still have a large capacity to bind Cd. Our results suggest that bioturbation by $A$. marina enhanced the contact of dissolved $\mathrm{Cd}$ with sediment particles enough to compensate for any reduction in $\mathrm{Cd}$ binding ability, resulting in an overall increase in $\mathrm{Cd}$ uptake in our study.

\section{Cadmium distribution in sediment - effects of Arenicola marina}

The activity of lugworms had a profound effect on $\mathrm{Cd}$ distribution. Within a few days a $\mathrm{Cd}$ peak arose at the feeding depth of $A$. marina $(10$ to $20 \mathrm{~cm})$. This peak became more distinct as exposure time increased. During its feeding process, Arenicola marina pumps and injects extensive amounts of water into the sediment around its feeding pocket, where Cd was bound. It has been suggested that lugworms stimulate a 'bacterial garden' at their feeding pocket (Hylleberg 1975). If so, the activities of bacteria and their meiofauna grazers (Reise 1995) may also enhance the adsorption of $\mathrm{Cd}$ here. There was a significant increase in Cd removal rate with lugworms present over the course of the experiment. This trend is consistent with the establishment and subsequent development of the lugworm's burrow and associated features, such as a microbial garden. While it is unclear what specific mechanisms are involved, the kinetics of $\mathrm{Cd}$ removal increased as the lugworms became more established in the sediment.

During prolonged feeding activity, particle-bound Cd was further spread by the lugworm's bioturbation. Thus, irrigation together with particle transport results in Cd being distributed more or less evenly throughout the sediment. Everaarts \& SaralaDevi (1996) observed a similar sequence of events in their experiment with Arenicola marina.

In the top layer of the sediment, $\mathrm{Cd}$ could be expected to be uniformly distributed because $\mathrm{Cd}$ diffused down from the overlying water across the entire interface. At depth, however, there could be greater lateral spatial heterogeneity, depending on the location of the lugworm burrow, size of the feeding pocket, etc. The lower concentrations we observed at depth may have resulted from localised 'hot spots' with high cd concentrations mixing together with uncontamınated sediments during the sediment sampling process. Thus, the distribution of $\mathrm{Cd}$ is likely to be more patchy at depth in bioturbated sediments.

\section{Cadmium binding capacity of sediment}

All sediment cores, regardless of whether lugworms were present or not, took up Cd throughout the entire experimental period, indicating that the capacity of the sediment for $\mathrm{Cd}$ binding had not been reached for any of the groups. Background $\mathrm{Cd}$ concentrations in Danish coastal waters are approximately $25 \mathrm{ng} \mathrm{l^{-1 }}$ (Magnusson \& Rasmussen 1982). The sediment we studied was capable of taking up large amounts of $\mathrm{Cd}$ from water containing 1 ppm $\mathrm{Cd}$, a concentration which is 40.000 times higher than the background concentration. Accordingly, these natural sediments probably represented an extensive sink for $\mathrm{Cd}$ and presumably other particle-reactive pollutants. That sediments can act as sinks for various metals was shown by Bryan \& Langston (1992).

The kinetics of $\mathrm{Cd}$ binding by the sediments in our experiment were influenced by the $\mathrm{Cd}$ concentration of the overlying water. The removal of $\mathrm{Cd}$ (exponential decrease) in overlying water was slower in cores containing 1 ppm $\mathrm{Cd}$, in spite of the irrigation rates being equal. This indicates that the sediment extraction of $\mathrm{Cd}$ from water (\% removed) was less effective in those systems due to the 40.000 -times-higher $\mathrm{Cd}$ concentration. These differences in $\mathrm{Cd}$ removal kinetics are probably of minor ecological relevance, however, as 
sediments containing lugworms will be very effective at removing $\mathrm{Cd}$ from the overlying water given the relatively low concentrations of $\mathrm{Cd}$ in even polluted waters (up to $1 \mu \mathrm{g} \mathrm{l}^{-1}$; Bryan \& Langston 1992).

\section{Influence of $\mathrm{Cd}$ on irrigation}

We were interested in whether sublethal concentrations of Cd would affect Arenicola marina's irrigation. This would be expected based on the results of others. For example, the ventilation rate of the polychaete Nereis virens increased when the animal was exposed to $30 \mathrm{ppb} \mathrm{Hg}$, decreased when exposed to $300 \mathrm{ppb}$ and almost ceased when exposed to $3000 \mathrm{ppb}$ (Miron et al. 1994). Observations from other experiments (Rasmussen unpubl.) showed that $A$. marina halts bioturbation when exposed to $10 \mathrm{ppm} \mathrm{Cd}$. Nevertheless, irrigation rates measured by $\mathrm{Br}^{-}$fluxes were not significantly different between control worms (A-) and worms exposed to $1 \mathrm{ppm} \mathrm{Cd}(\mathrm{A}+\mathrm{Cd})$ in this experiment. This suggests that the effect of $\mathrm{Cd}$ on irrigation by $A$. marina may be quite abrupt, with a threshold for inhibiting irrigation somewhere between 1 and $10 \mathrm{ppm}$ Cd. More work concentrating on the dose-response for Cd concentrations between 1 and $10 \mathrm{ppm}$ is required to see if this response pattern is true for $A$. marina. Apparently, irrigation rates were high enough in all groups to ensure that essentially all the Cd in the overlying water was pumped down into the sediment and absorbed during the course of the day.

\section{Environmental implications}

The bioturbation of Arenicola marina greatly enhances the rate at which particle-reactive metals such as $C d$ can be taken up or scavenged by sediments. Also, the lugworm was important for redistributing $\mathrm{Cd}$ over a greater zone within the sediments. The result of this is that heavy metal scavenging from contaminated waters is enhanced, but also that a larger zone within the sea floor is contaminated in the process. While we did not investigate the opposite scenario in our study, that is contaminated sediments overlain by uncontaminated waters, one can speculate that the effects of bioturbating infauna such as the lugworm could also be reversed, stimulating the release of particle-bound contaminants to the overlying water. Everaarts \& SaralaDevi (1996) did observe mobilisation of sedimentbound $\mathrm{Cd}$ as a result of bioturbation by $A$. marina.

If the metal is dissolved in the overlying water or within a limited surficial layer in the sediment, then the deep burrowing, deep irrigating lugworm will help transfer heavy metals to deeper layers of the sediment, thus locking it safely away. If, on the other hand, the contaminant is already distributed deeply within the sediments, then the deep bioturbation of the lugworm will likely insure that some fraction of the contaminant is mobilised, constantly cycling within the environment.

Bioturbation by different infauna species is undoubtedly important in determining the distribution and fate of particle-bound pollutants. This is a complicated topic that is only just beginning to be appreciated and investigated (see e.g. Forbes \& Forbes 1994, Kure \& Forbes 1997).

Acknowledgements. This work was supported by a grant from the Danish National Research Council to O.A. The authors thank Pernille Greve and Anna-Elisa Egholm for valuable technical assistance as well as Karen Timmerman and Jan Christensen for their help with modelling of irrigation. The manuscript was greatly improved after comments by Hans Ulrich Riisgård and 4 anonymous reviewers.

\section{LITERATURE CITED}

Aller RC, Aller JY (1992) Meiofauna and solute transport in marine muds. Limnol Oceanogr 37(5):1018-1033

Bryan GW, Langston WJ (1992) Bioavailability, accumulation and effects of heavy metals in sediments with special reference to United Kingdom estuaries: a review. Environ Pollut 76:89-131

Cadée GC (1976) Sediment reworking by Arenicola marina on tidal flats in the Dutch Wadden Sea. Neth J Sea Res 10 : $440-460$

Daniel WW (1995) Biostatistics: a foundation for analysis in the health sciences. John Wiley and Sons, Inc, New York

Davey JT, Watson PG (1995) The activity of Nereis diversicolor (Polychaeta) and its impact on nutrient fluxes in estuarine waters. Ophelia 41:57-70

Davies-Colley RJ, Nelson PO, Williamson KJ (1984) Copper and cadmium uptake by marine sediment phases. Environ Sci Technol 18(7):491-499

Di Toro DM, Mahony JD, Hansen DJ, Scott KJ, Hicks MB, Mayr SM, Redmond MS (1990) Toxicity of cadmium in sediments: the role of acid volatile sulphide. Environ Toxicol Chem 9(9):1487-1502

Everaarts JM, SaralaDevi K (1996) Cadmium distribution in sediment and the lugworm Arenicola marina in a low concentration exposure experiment. Bull Environ Contam Toxicol 57:771-778

Forbes VE, Forbes TL (1994) Ecotoxicology in theory and practice. Chapman and Hall, London

Förstner U, Wittmann GTW (1979) Metal pollution in the aquatic environment. Springer-Verlag, Berlin.

Gerino M, Stora G (1991) Analyse quantitative in vitro de la bioturbation par la polychaete Nereis diversicolor. C R Acad Sci Ser III 489-494

Hüttel M (1990) Influence of the lugworm Arenicola marina on porewater nutrient profiles of sand flat sediments. Mar Ecol Prog Ser 62:241-248

Hylleberg J (1975) Selective feeding by Abarenicola pacifica with notes on Abarenicola vagabunda and a concept of gardening in lugworms. Ophelia 14:113-137

Jensen A, Markussen. J (1993) Forbrug af og forurening med cadmium. Use of and pollution by cadmium. Environmen- 
tal Project no. 213. Danısh Environmental Protective Agency, Copenhagen

Jones SE, Jago CF (1993) In situ assessment of modification of sediment properties by burrowing invertebrates. Mar Biol $115: 133-142$

Klerk PL, Weis JS (1987) Genetic adaptation to heavy metals in aquatic organisms: a review. Environ Pollut 45:173-205

Krantzberg G (1985) The influence of bioturbation on physical, chemical and biological parameters in aquatic environments: a review. Environ Pollut 39A:99-122

Kristensen $E$ (1984) Effect of natural concentrations on nutrient exchange between a polychaete burrow in estuarine sediment and the overlying water. J Exp Mar Ecol 75: $171-190$

Kure LK, Forbes TL (1997) Impact of bioturbation by Arenicola marina on the fate of particle-bound fluoranthene. Mar Ecol Prog Ser 156:157-166

Magnusson B, Rasmussen L (1982) Trace metal levels in coastal sea water. Investigation of Danish waters. Mar Pollut Bull 13(3):81-84

Mantoura RFC, Dickson A, Riley JP (1978) The complexation of metals with humic materials in natural waters. Estuar Coast Mar Sci 6:387-408

Miron G, Brock V, Kristensen E (1994) Effects of mercury on the ventilation behaviour of the polychaete Nereis virens (Sars). J Exp Mar Biol Ecol 184:67-81

Nriagu JO (1988) A silent epidemic of environmental metal

Editorial responsibility: Otto Kinne (Editor),

Oldendorf/Luhe, Germany poisoning. Environ Pollut 50:139-161

Presley BJ (1971) Techniques for analysing interstitial water samples. Part 1: Determination of selected minor and major inorganic constituents. Initial Rep Deep Sea Drilling Project. 7(2):1749-1755

Reise K (1995) Tidal flat ecology. Springer-Verlag, Berlin

Riisgård HU, Berntsen I, Tarp B (1996) The lugworm (Arentcola marina) pump: characteristics, modelling and energy cost. Mar Ecol Prog Ser 138:149-156

Rijken M (1979) Food and food uptake in Arenicola marina Neth J Sea Res 13(3/4):406-421

Simpson WR (1981) A critical review of cadmium in the marine environment. Prog Oceanogr 10:1-70

Sokal RR, Rohlf FJ (1981) Biometry, 2nd edn. WH Freeman and Company, New York

Thomann RV, Merklin W, Wright B (1993) Modelling cadmium fate at Superfund site: impact of bioturbation. J Environ Engineer 119(3):424-442

Thomsen U, Kristensen E (1997) Dynamics of $\Sigma \mathrm{CO}_{2}$ in a surficial sandy marine sediment: the role of chemoautotrophy. Aquat Microb Ecol 12(2):165-176

Wells GP (1963) Barriers and speciation in lugworms. Syst Assoc Publ 5:79-98

Wells GP (1966) The lugworm (Arenicola) - a study in adaptation. Neth J Sea Res 3(2):294-313

Zar H (1984) Biostatistical analysis. Prentice-Hall, Englewood Cliffs, NJ

Submitted: August 18, 1997; Accepted: January 19, 1998

Proofs received from author(s): March 19, 1998 